\title{
Prospective petroleum accumulation areas in the non-structural traps in the Upper Permian sequences of the southern part of the Vilyuy Syneclise (Eastern Siberia)
}

\author{
G.A. Cherdancev \\ Postgraduate student, Saint-Petersburg Mining University, Russia
}

\author{
V.P. Semenov \\ Candidate of Geological and Mineralogical sciences, leading researcher, Joint-Stock company "All-Russia \\ Petroleum Research Exploration Institute» ( «VNIGRI»), Russia
}

I.A. Kushmar

Candidate of Geological and Mineralogical sciences, head of department, Joint-Stock company "All-Russia Petroleum Research Exploration Institute» ( $V V N I G R I »)$, Russia

\begin{abstract}
The article provides the updating of the petroleum potential forecast of the Permian formations in the southern part of the Vilyuy Syneclise, which is a promising territory for the petroleum exploration. Article includes a brief description of the Upper Permian sequences and justification of the oil and gas prospects of the Upper Permian Taragay Formation. Authors have performed updated scheme of the oil and gas potential prospects of the Permian section based on the data of new geological and geophysical studies carried out in the southern part of the syneclise.
\end{abstract}

\section{INTRODUCTION}

The current issue in the east of Russia - in Yakutia - is certain risks associated with the provision and refill of the energy and industrial sectors of the national economy with petroleum resources (Sivtsev, Chalaya et al., 2016). One solution to this problem is exploration of new accumulation areas in Central Yakutia.

Vilyuy Syneclise is one of the areas in Eastern Siberia, where researchers expect discovery of new petroleum accumulations in the Upper Paleozoic formations.

Vilyuy Syneclise is the largest depression in the east of the Siberian Platform. The syneclise is located on a large territory between the Anabar Anteclise in the north and Aldan Anteclise in the south; in the east the syneclise borders on the Pre-Verkhoyansk Trough. The geological structure of the sedimentary cover includes formations from the Upper Proterozoic to Cenozoic systems.

The petroleum potential of the Permian section of the Vilyuy Syneclise is confirmed by the presence of accumulations in the Upper Permian formations (gas and gas condensate fields in the central part of the syneclise - within the Khapchagay Uplift Area), as well as oil and gas occurrences within the syneclise.

Different researchers have repeatedly pointed out the possible oil and gas prospects of the Permian section in the south of the Khapchagay Uplift Area (Sitnikov et al., 2014, Vasiliev et al, 2018). The geological and geophysical studies recently conducted by JSC "Yakutskgeofizika" and JSC "VNIGRI" in the southern part of the syneclise confirm the prospects of Permian formations in this area. 


\section{BRIEF GEOLOGICAL CHARACTERISTICS OF THE STUDIED AREA AND UPPER PERMIAN FORMATIONS}

The studied area is about 12 thousand $\mathrm{km}^{2}$. In general, the Permian structural plan of this territory is the southern monoclinal slope of the Vilyuy Syneclise. It is complicated mainly by structural elements such as structural noses, flexures, etc. In the northeast of the territory there is the Tangnaryn Depression adjacent to the Khapchagay Uplift Area from the south. In the southwest of the studied area there are Ygyattin and Kempendyay depressions, which are separated by the Suntar Arch. The Arbaysk-Sinsk Uplift Area is located to the southeast from the Kempendyay Depression; from the southeast it is limited by the Sarsan Depression. To the east there is a northwest side of the Aldan Anteclise (Figure 1).

The Permian formations are widespread throughout the studied territory. Their thickness varies from $3.6 \mathrm{~km}$ in the central part of the Tangnaryn Depression to wedging-out closer to the sides of the syneclise. The subdivision of the Permian sequences is based on the presence or absence of coal layers.

The terrigenous-coal-bearing Permian section in the south and in the center of the syneclise is divided into the Lower Permian Mohsogolokh Formation and the Upper Permian Khomustah, Kharyass, Kyundey, and Taragay formations. A comparison of the time of their formation with the international stratigraphic chart and the general stratigraphic chart, used in the period of time when they were described, is presented in Figure 2. These formations are dominantly composed of sandstones, layers of interbedded siltstones and mudstones (Frolov et al, 2019). They were formed in continental sedimentation environments.

Gas-bearing reservoir rocks of the Upper Permian formations in the central part of the syneclise are confined to the Taragay Formation of the Tatarian series of the Permian system. The main type of deposits is lithologically screened roof deposit.

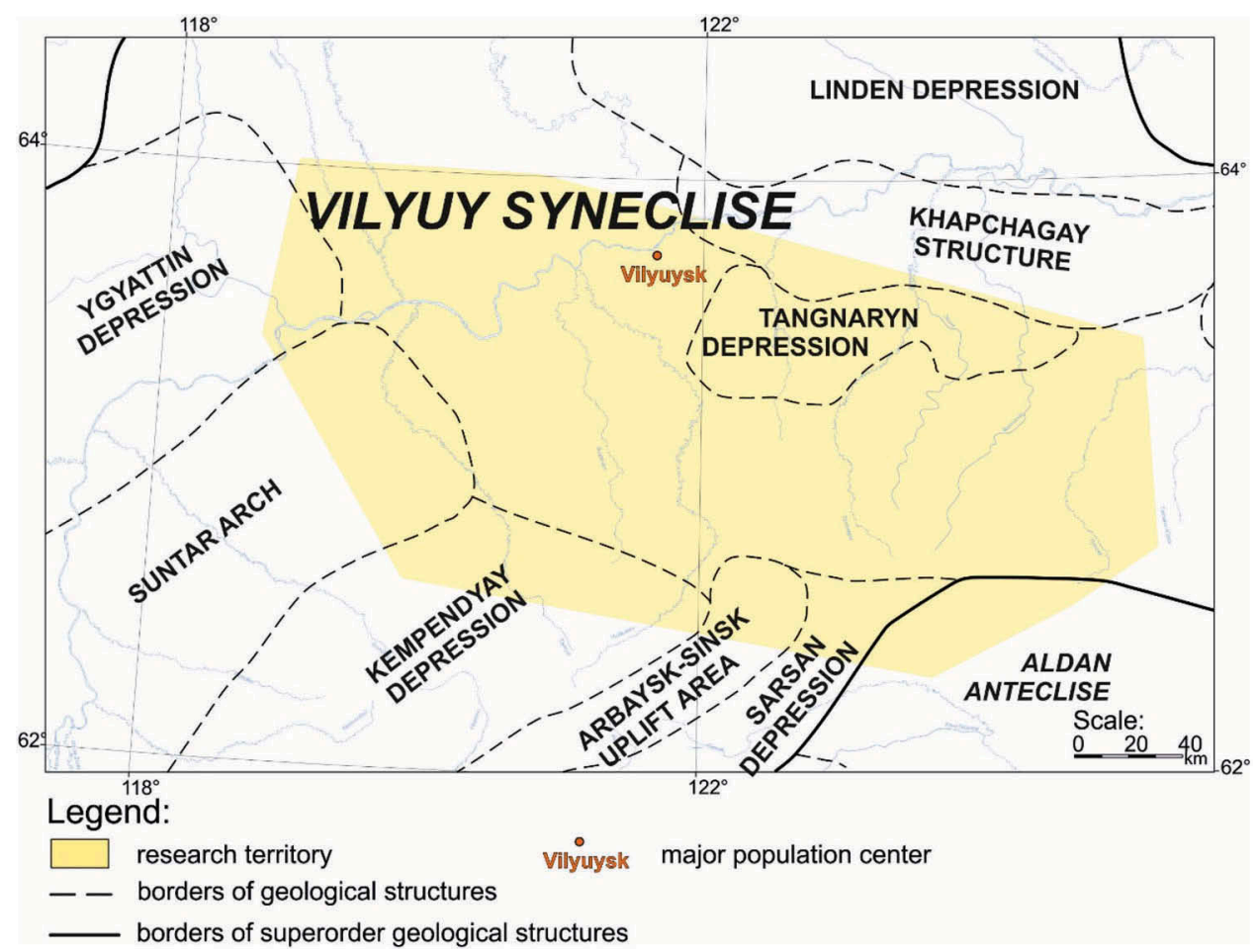

Figure 1. Structural and tectonic schematic view of the research territory. 

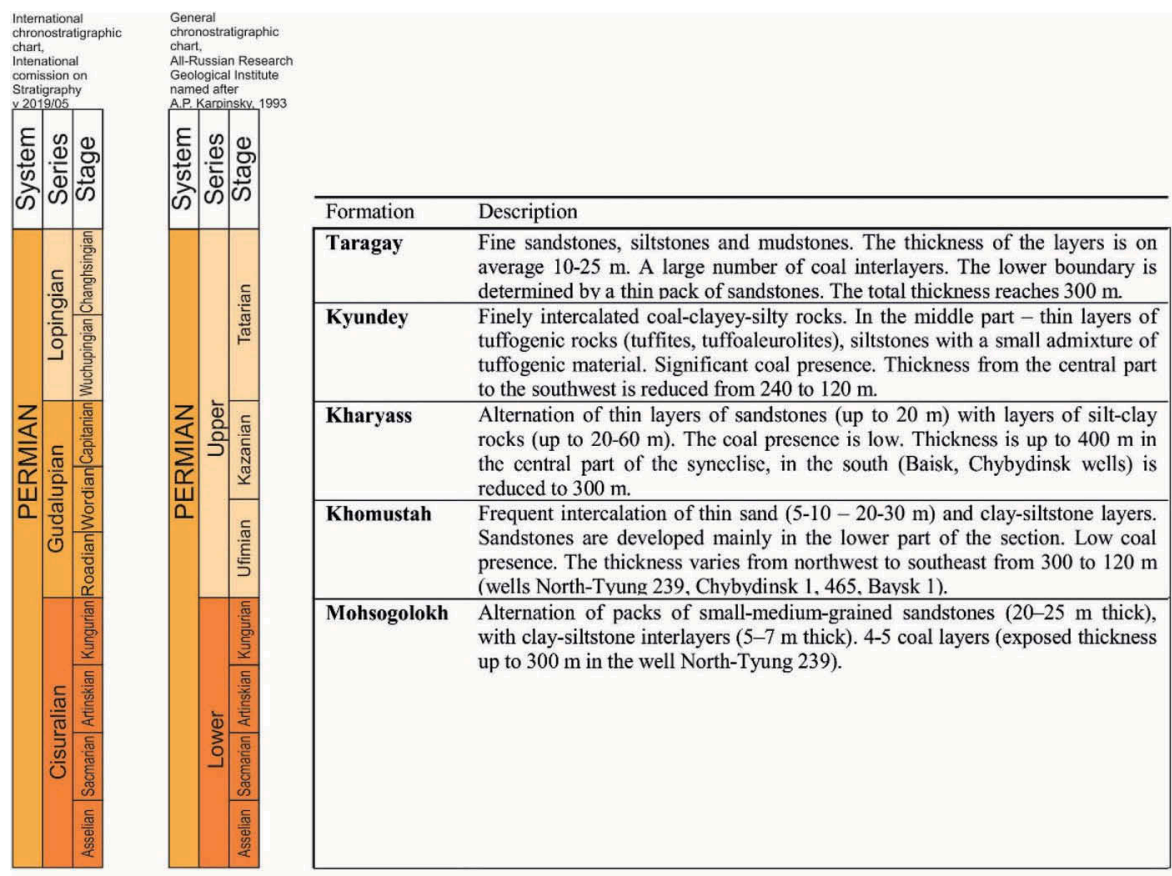

Figure 2. Description of the Permian formations of the southern part of the Vilyuy Syneclise.

The Taragay Formation was drilled by 26 wells within the studied territory; however, its full section was exposed only in wells of the Khapchagay Uplift Area. The formation is composed by thin layers of sandstones and carbon-bearing-clayey-siltstone rocks with thickness up to 10-15 m. Thin layers of tuffogenic rocks are exposed in the top of the formation. Taragay Formation on the southern side of the Vilyuy Syneclise was formed in the continental sedimentation environments. The section formed in the beds of meandering rivers, their floodplains, lakes and swamps, are widespread within the territory. The thickness of the formation within the site decreases from $304 \mathrm{~m}$ on the south (Middle Vilyuy 27 well (27_Sr-Vil)) to 85.9 m (Bappagay 1 well (1_Bapp)).

Permeable rocks of the upper part of the Permian section were discovered in the South Byrakan area (Byrakan wells (1184_Byr, 3_Byr, 2_Byr)). The porosity of the reservoirs reaches $14.2 \%$.

Satisfactory pore reservoirs are also discovered in Baysk 1 well (1_Bays) with a porosity of $14-15.8 \%$; during the tests the water inflow of $14.25 \mathrm{~m}^{3} /$ day was reached.

In the South Nedzhelinsk well (251_Y-Nedj) the natural gas inflow up to $1000 \mathrm{~m}^{3} /$ day was obtained from Permian formations (Sitnikov et al., 2017).

During tests in Hailakh 1213 well (1213_Hayl) the inflows of water with dissolved gas were obtained; core porosity of the reservoir rocks of the Taragay Formation was up to $9.4 \%$. The reservoir properties are also confirmed by the results of re-interpretation of well logs carried out by specialists of JSC "VNIGRI".

Reliable impermeable rocks for the potential Taragay Formation are the Lower Triassic Nedzhelinsk Formation, regionally developed on the territory of the Vilyuy Syneclise (Vasiliev et al, 2018). The Nedzhelinsk Formation is not distributed throughout the whole territory. On the remaining territory, the lower part of the Lower Jurassic Kyzylsyr Formation, which overlaps the Permian formations in the south where Triassic formations are absent, may serve as possible reservoir caprock due to its impermeable properties. In addition, there are impermeable layers of clay rocks within the Taragay Formation that can serve as local reservoir caprocks. 


\section{PERMIAN SOURCE ROCKS OF THE VILYUY SYNECLISE}

The Permian terrigenous structure is the main oil and gas producing formation for the Upper Paleozoic-Mesozoic sedimentary sequences of the basin (Zueva et al., 2014). Due to the high bio-productivity of the continental Permian landscapes, the large masses of organic matter are accumulated in this section.

The dispersed organic matter (DOM) of the Permian sequences has a mixed genetic nature with a different ratio of sapropelic and humic components, but is mainly represented by sapropelic and humic types (Zueva et al., 2014).

By the beginning of the Triassic, the Permian sequences entered the initial stage of the main phase of oil formation in the depressions in the south of syneclise. On the territory of the Linden Depression and the present-day Khapchagay Uplift Zone, they approached the main stage of gas generation. In subsequent eras, the Permian sequence continued to plunge unevenly. Subsidence depths were determined by the thickness of the overlying sections, which created various conditions for the generation and migration of hydrocarbons.

To the end of the Lower Cretaceous, the Permian sequences in most of the territory were located at the levels of the main gas generation zone, corresponding to the stage of maximum migration of gas hydrocarbons, while in the Linden Depression - to the stage of gas process attenuation.

At the present stage, corresponding to the depths of maximum deposits subsidence, the Permian formations are located almost throughout the territory within the gas generation zone. In the deepest parts of the depressions, the Permian section could have exhausted their gasproducing properties.

Thus, starting from the Triassic time, the hydrocarbon migration could occur from the most deepened part of the syneclise to its sides, where they could be accumulated in traps.

\section{OIL AND GAS PROSPECTS}

There are not many typical anticlinal traps in the studied area. They were identified earlier (Byrakan, Hailakh sites); wells were drilled within them, in which gas inflows were received during well tests. No other large anticlinal traps have been identified; therefore, the oil and gas accumulation zones within the studied area can be primarily confined to non-anticlinal traps. Favorable factors for their formation are the presence of interbedded sand and clay rocks, large regional Pre-Triassic and Pre-Jurassic erosion, on the surfaces of which the porous and impermeable rocks come into contact, the development of facial substitution areas and regional wedging out of sequences that are characterized by oil and gas potential. The positive impact of such factors on the oil and gas potential is also known in other oil and gas basins in Russia (Prishchepa et al, 2019; Borovikov and Volchenkova, 2018).

The identification of promising zones of oil and gas accumulation was preceded by a detailed correlation of productive levels, structural and tectonic studies based on seismic, electrical, and gravimetric surveys, which allow us to clarify the structural plans for prospective petroleum bearing areas within the territory and to update the pinch-out line of the Permian sequences.

As an example, the fragment of seismic survey interpretation performed by JSC «Yakutskgeofizika» specialists is provided in Figure 3, where the pinching out of the Permian sedimentary complex is presented.

Figure 4 shows the same seismic section with a possible petroleum prospect in the Upper Permian sedimentary rocks.

As a result of research, promising oil and gas zones were localized in the upper part of the Permian section (Figure 5).

In the eastern part of the research area, a promising prospecting object is limited from the northwest by tectonic fault traced along seismic sections. The level of oil and gas content was 


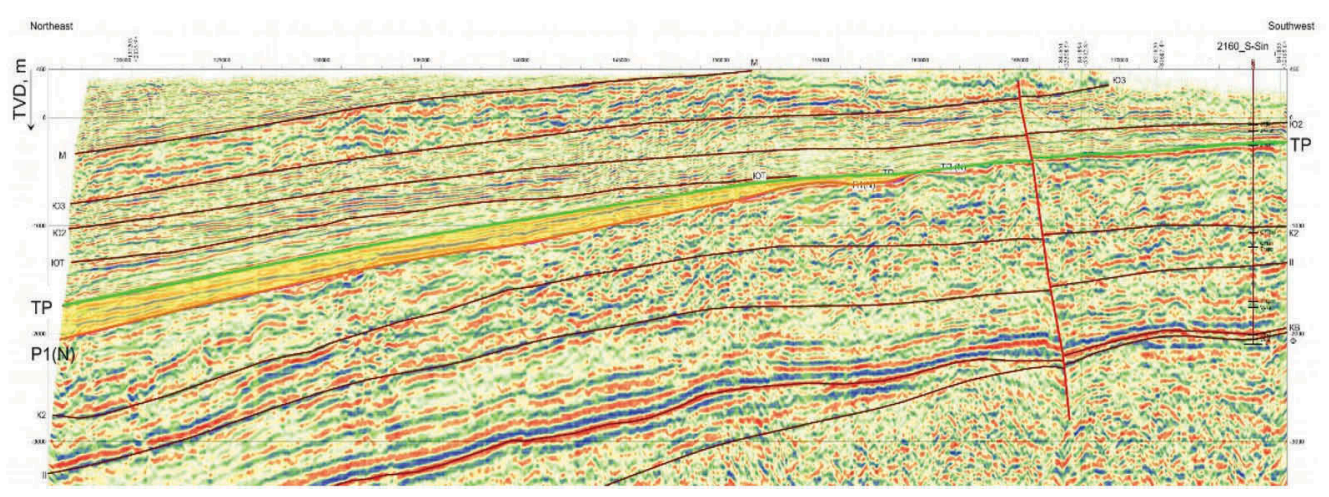

Figure 3. Fragment of the seismic section. TP (green) -top of the Upper Permian formation (Taragay Fm); P1(N) (orange) - bottom of the Upper Permian formations; the interval of the Upper Permian section is shown in yellow.

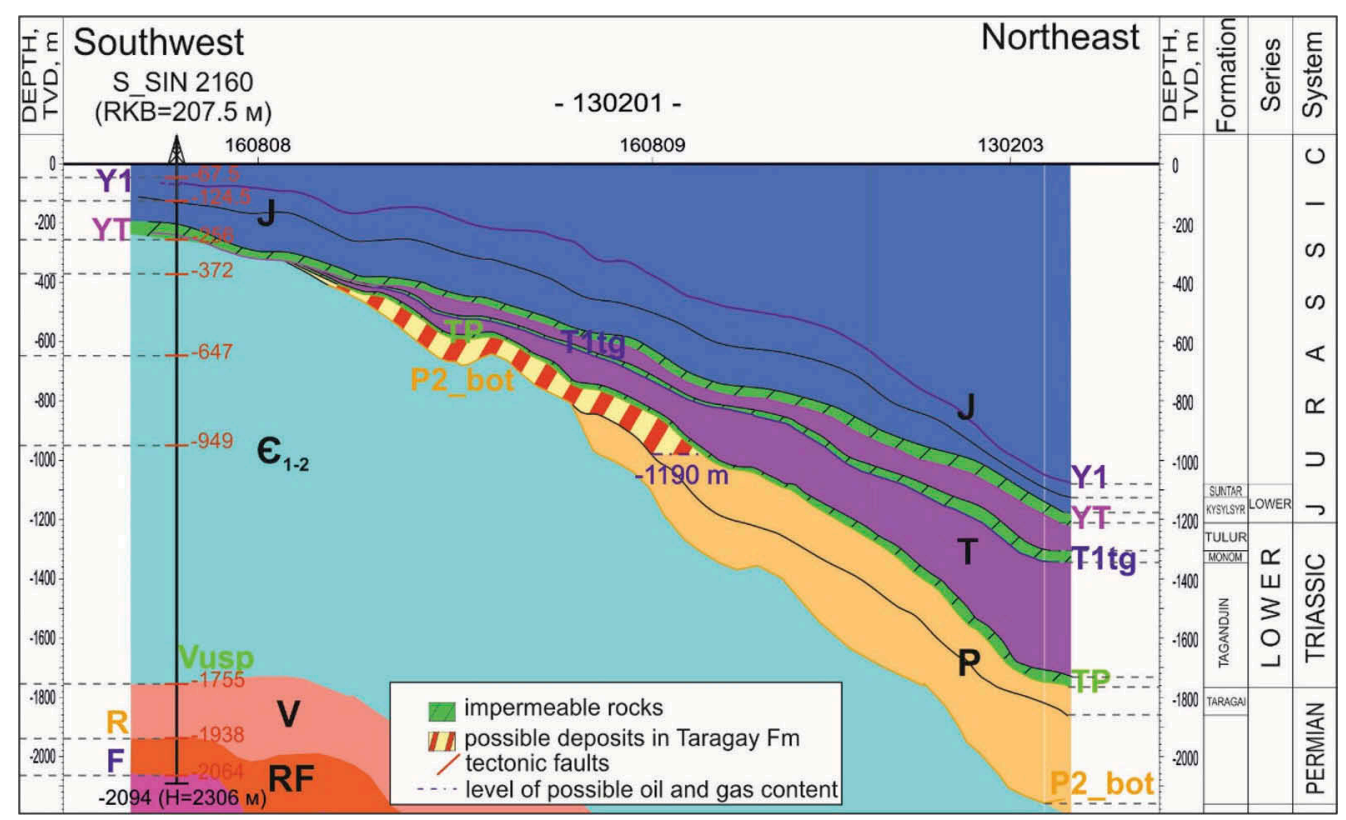

Figure 4. Fragment of the geological section.

Seismic horizons: Y1- top of Suntar Fm (J1sun); YT- top of Tulur Fm (T1t1); T1tg- top of Tagandjin Fm (T1tg); TP- top of Taragay (P2tr); P2_bot - bottom of Upper Permian formations; R- top of Riphean sequences; F - top of basement rocks

taken at an absolute depth (TVD) of $-1190 \mathrm{~m}$, corresponding to the top of water-saturated reservoirs according to well log data in Andreevsk 2 well (2_Andr) located nearby. In the south the perspective zone is limited by the wedging line of the Taragay Formation, traced on seismic surveys sections and deep well drilling data.

In the western part of the site, the prospecting object is bounded from the southwest by the pinch-out line of the Permian sequences, and by tectonic faults that limit the Suntar Arch from neighboring depressions. The probable oil and gas content level has an absolute depth $-1300 \mathrm{~m}$, which corresponds to the top of the water-saturated reservoir in the Nizhnetyukyan 311 well (311_N-Tuk). 


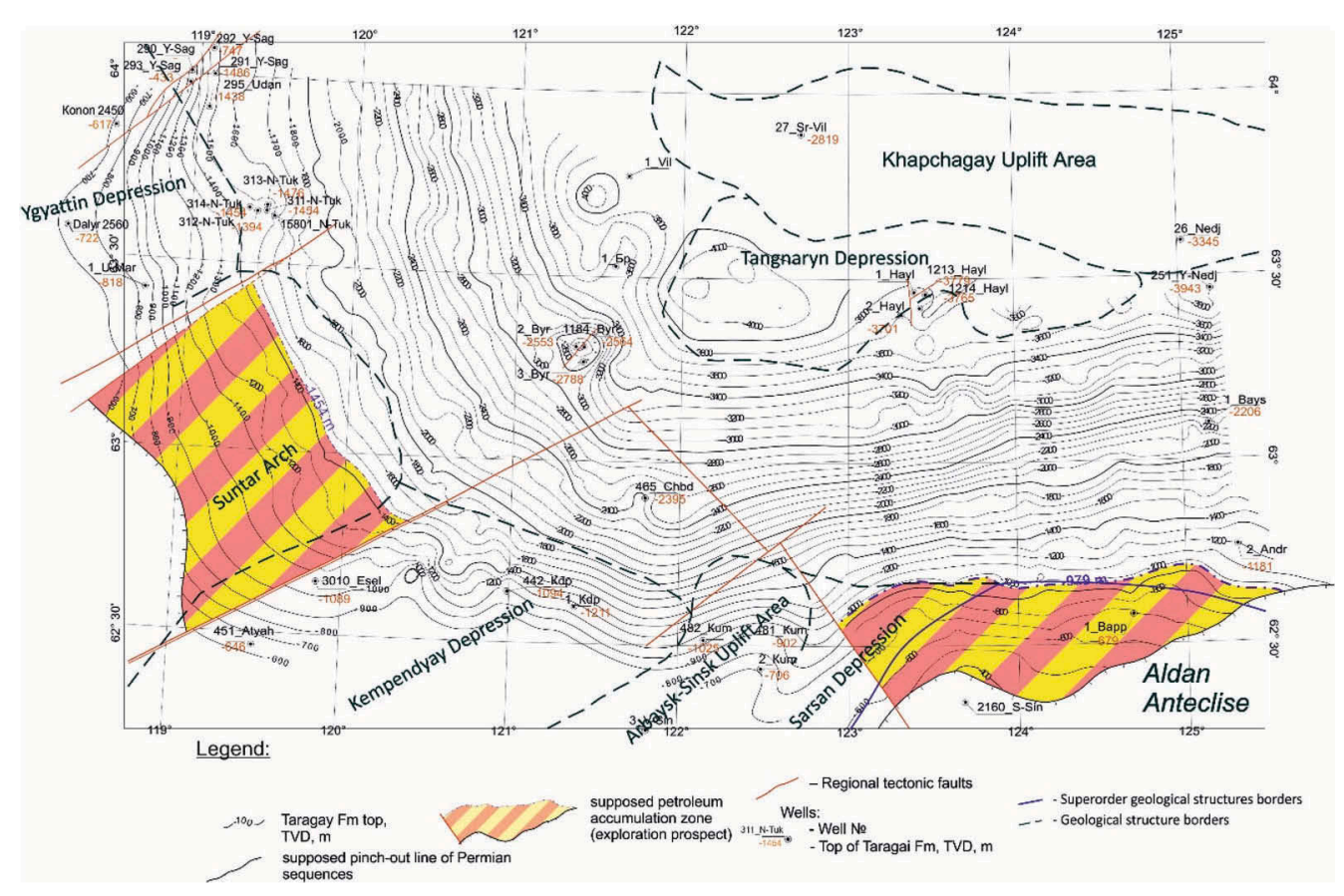

Figure 5. Scheme of oil and gas prospects of the Permian section in the southern part of the Vilyuy Syneclise.

\section{CONCLUSIONS}

The Permian oil and gas structure is associated with certain prospects for the discovery of hydrocarbon accumulations in the southern part of the Vilyuy Syneclise. Non-anticlinal traps are expected there. They are controlled by the surfaces of erosion, limiting the Permian sequence from below and above, as well as by the development of weakly permeable or impermeable rocks below the surface of the Pre-Permian erosion. Other factors are the distribution of clay rocks above the Triassic erosion surface and facial variability within the Permian section.

As a result of the studies conducted by VNIGRI specialists on the basis of complex geological and geophysical surveys, the perspective objects in the Upper Permian were localized within the research object and the pinching out boundaries of the Permian formations were clarified.

The traps in the selected zones are assumed to be of non-structural type and will be confined to the zones of pinch-out of productive reservoir rocks and controlled by regional lithological screens.

The types of deposits associated with these traps are stratigraphic, lithological and stratigraphic with elements of tectonic shielding.

The obtained geological results indicate the need for further study of this territory.

\section{REFERENCES}

Borovikov I.S., Volchenkova T.B. 2018. Model of forming hydrocarbon pools in the west of Melekess depression. Conference Proceedings, Innovations in Geosciences. Time for Breakthrough, Saint Petersburg, Apr 2018, (2018): 1-6. EAGE.

Frolov S.V., Karnyushina E.E., Korobova N.I., Bakay E.A., Kurdina N.S., Krylov O.V., Tarasenko A. A. 2019. Features of the structure, sedimentary complexes and hydrocarbon systems of the Leno-Vilyuisky oil and gas basin. Georesources 21(2): 13-30. 
Prishchepa, O., Nefedov, Y., \& Grokhotov, E. 2019. Geochemical and petrophysical studies of hydrocarbon potential of domanic shale formation (the timan-pechora petroleum province). Conference Proceedings, EAGE/SPE Workshop on Shale Science 2019, Apr 2019, (2019): 1-5. EAGE.

Sitnikov V.S., Alekseev N.N., Pavlova K.A., Pogodaev A.V., Sleptsova M.I. 2017. Newest forecast and development updating of Vilyuy Syneclise petroleum objects. Petroleum Geology - Theoretical and Applied Studies 12 (1).

Sitnikov V.S., Prishchepa O.M., Kushmar I.A., Pogodaev A.V. 2014. Petroleum potential prospects of southern part of Vilyusky syneclise. Prospect and protection of mineral resources 7: 22-28.

Sivcev A.I., Chalaya O.N., Zueva I.N. 2016. Prospects of oil and gas in the Central Yakutia as resource of energy security. Oil and Gas Business 2: 71-82.

Vasiliev S.A., Sobolev P.N., Taffarel E.S., Golovanova M.P., Garifullin I.I. 2018. Oil and gas potential of Vilyuiskaya syneclise and prospects of hydrocarbon deposits searching. Geology, geophysics and development of oil and gas fields 12: 14-26.

Zueva I.N., Chalaya O.N., Safronov A.F., Kashircev V.A. 2014. Oil Generated Potential of the Permian Deposits of the Vilyui Basin. Science and Education 2: 110-117. 